\title{
PROLONGED SECOND STAGE LABOUR AND CONSEQUENCES OF HYPOXIA IN THE NEONATE: A REVIEW
}

\author{
P. MARTZ ${ }^{1}$, P. GEORGIEV ${ }^{2}$ \& A. WEHREND ${ }^{1}$
}

\begin{abstract}
${ }^{1}$ Clinic for Obstetrics, Gynecology and Andrology of Large and Small Animals, Justus-Liebig-University, Gießen, Germany; ${ }^{2}$ Department of Obstetrics, Reproduction and Reproductive Disorders, Faculty of Veterinary Medicine, Trakia University, Stara Zagora, Bulgaria
\end{abstract}

\section{Summary}

Martz, P., P. Georgiev \& A. Wehrend, 2019. Prolonged second stage labour and consequences of hypoxia in the neonate: A review. Bulg. J. Vet. Med., 22, No 2, 131-142.

Hypoxia due to dystocia and its repercussions are serious issues concerning the health of neonates. In order to gain a better understanding of the cause and especially the effects and potential long-term disorders, a critical analysis of peer-reviewed literature was made. As shown by many authors, initially the most devastating peripartal cause of ill health in neonates is associated with the serious effects of prolonged and severe acidosis. Other life threatening complications are related to disorders such as meconium aspiration syndrome (MAS), neonatal respiratory distress syndrome, hypoxic ischaemic encephalopathy and necrotising enterocolitis. Despite the astonishing ability of neonates to compensate mixed metabolic and respiratory acidosis with breathing onset directly postpartum, the longer second stage labour takes and the more extreme the acidosis is, the more detrimental its consequences. Lungs are especially vulnerable in this phase of life, aspired meconium can result in increased expression of pro-inflammatory chemotactic cytokines, phospholipase $\mathrm{A}_{2}$ and $\mathrm{PGE}_{2}$ levels , exacerbating inflammatory reactions of lung tissue and exerting a deleterious effect on alveolar cells. Neonates experiencing dystocia could greatly benefit from administration of buffering substances and non-steroidal anti-inflammatory drugs.

Key words: acidosis, foetal stress, hypoxia, meconium, neonates

\section{INTRODUCTION}

Neonatal mortality in farm animals continues to be high, so from an economic and animal welfare perspective a high motivation exists to reduce this death rate. One major cause of neonatal death is in- tra-uterine hypoxia during second stage labour. The aim of this review is to elucidate the patho-physiological mechanisms of hypoxia and its negative effects on vitality of neonates with focus on the lungs. 


\section{FOETAL/PERINATAL METABOLISM. BLOOD GAS AND ACID-BASE DYNAMICS AT PARTURITION}

\section{Eutocia}

Foetal growth and vitality depend on the supply of nutrients and oxygen and removal of metabolic wastes and carbon dioxide made possible through the intricate relationship between mother, placenta and foetus (Tucker \& Hauth, 1990; MotaRojas et al., 2011). With the onset of second stage labour the umbilical cord is temporarily occluded during abdominal contractions and the placental membranes begin detaching. This causes a disruption in the blood flow through the placenta depriving the foetus from oxygen as well as nutrients (Walser \& Maurer-Schweizer, 1978; Rurak et al., 1990; Tucker \& Hauth, 1990; Alonso-Spilsbury et al., 2005; Castro-Najera et al., 2006; Taverne $\&$ Noakes, 2009). The circulatory disruption of the uteroplacental unit causes a mixed metabolic respiratory acidosis.

Walser \& Maurer-Schweizer (1978) as well as Rurak et al., (1990) and some others affirm that the physiological hypoxia and hypercapnia experienced by the foetus during birth, makes it switch to oxygen-saving circulation sparing the heart, central nervous system (CNS) and adrenal gland.

During the perinatal period and shortly after birth the foetus and then the neonate depends on its hepatic glycogen reserves, gluconeogenesis and switches to anaerobic metabolic pathways to sustain itself, which causes an increase in lactic acid resulting in a metabolic acidosis (Walser \& Maurer-Schweizer, 1978; Patterson et al., 1987; Szenci, 2012; Bleul \& Götz, 2013). This anaerobic phase also causes a mild respiratory acidosis reflected in a decreased blood $\mathrm{pH}$ and an increased base deficit (Comline \& Silver, 1972; Busse et al., 1986; Kumar \& Paterson-Brown, 2010). At birth all vital functions such as blood oxygenation, $\mathrm{pH}$ maintenance, thermoregulation and normoglycaemia are transferred over to the neonate. The respiratory acidosis, hypercapnia, is a major incentive to begin breathing, necessary for subsequent independent life. Thrifty neonates have an astonishing ability to self-correct metabolic and respiratory imbalances due to hypoxia, with the respiratory component subsiding quickly and the metabolic component: within 24- 48 hours (Comline \& Silver, 1972; Walser \& Maurer-Schweizer, 1978; Bostedt \& Bellinghausen, 1985; Busse et al., 1986; Szenci et al., 1988; Herpin et al., 1996; Varga et al., 2001; Gorlt, 2004; Richter, 2005; Walser, 2009; Poulsen et al., 2009; Schultz, 2009; Taverne \& Noakes, 2009; Blomhoff Holm, 2012; Bleul \& Götz, 2013). Table 1 shows an overview of the literature on $\mathrm{pH}$, $\mathrm{pCO}_{2}$ and base excess (BE) values in different neonates.

\section{Acid-base status in eutocia}

Blood $\mathrm{pH}$ values of neonates are a wellestablished parameter measured to assess the thriftiness of newborn infants. Comline \& Silver (1972) and Busse et al. (1986) presented similar findings in their studies with thrifty lambs, and demonstrated that blood $\mathrm{pH}$ around parturition was $<7.20$ and 7.18, respectively. Both research teams also showed that once breathing was established, the $\mathrm{pH}$ normalised quickly, within 30-60 minutes and 12 hours respectively. Several authors showed that thrifty neonates begin life with blood $\mathrm{pH}$ below average spanning from 7.20 to 7.31 and $\mathrm{pCO}_{2}$ above average, 51.0 to $70.4 \mathrm{mmHg}$ (Table 1). The cause of the abnormal blood parameters is 
Table 1. Overview of $\mathrm{pH}, \mathrm{pCO}_{2}$ and $\mathrm{BE}$ in thrifty bovine and equine neonates ( $\mathrm{v}=$ venous blood, $\mathrm{a}=$ arterial blood)

\begin{tabular}{|c|c|c|c|c|}
\hline Reference & $\begin{array}{l}\text { Animal } \\
\text { species }\end{array}$ & $\begin{array}{c}\text { Mean } \\
\text { blood } \mathrm{pH}\end{array}$ & $\begin{array}{c}\mathrm{pCO}_{2} \\
(\mathrm{mmHg})\end{array}$ & $\begin{array}{c}\mathrm{BE} \\
(\mathrm{mmol} / \mathrm{L})\end{array}$ \\
\hline Walser \& Maurer-Schweizer (1978) & bovine & $\begin{array}{l}\text { ca. } 7.20(\mathrm{v}) \\
15 \text { min. p.n. }\end{array}$ & ca. 65 & ca. -4 \\
\hline Bostedt \& Bellinghausen (1985) & equine & $\begin{array}{l}\text { ca. } 7.25(\mathrm{v}) \\
\text { at birth }\end{array}$ & 67 & $\begin{array}{l}\text { large indivi- } \\
\text { dual variance }\end{array}$ \\
\hline Szenci et al. (1988) & bovine & $\begin{array}{l}7.31(\mathrm{v}) \\
\text { at birth }\end{array}$ & $51.0^{*}$ & 0 \\
\hline Herfen (1999) & bovine & $\begin{array}{l}7.28(\mathrm{v}) \\
\text { at birth }\end{array}$ & 62.58 & 0.40 \\
\hline Varga et al. (2001) & bovine & $\begin{array}{l}7.26(\mathrm{a}) \\
5 \text { min. p.n. }\end{array}$ & 59.8 & -2.3 \\
\hline Gorlt (2004) & equine & $\begin{array}{l}7.27(\mathrm{v}) \\
\text { at birth }\end{array}$ & 70.38 & 2.42 \\
\hline Richter (2005) & bovine & $\begin{array}{l}7.28(\mathrm{a}) \\
\text { at birth }\end{array}$ & $63.46^{*}$ & 0.97 \\
\hline Bleul \& Götz (2013) & bovine & $\begin{array}{l}7.24(\mathrm{v}) \\
10 \min p . n .\end{array}$ & 61.35 & -2.5 \\
\hline
\end{tabular}

*converted from kilopascals into millimeters mercury (Szenci et al., 1988: 6.8 kPa; Richter, 2005: $8.46 \mathrm{kPa}$; factor 7.5006168).

a mixed metabolic and respiratory acidosis caused by the birthing process. Most authors affirm that the respiratory component subsides faster, according to others the metabolic acidosis was more important but all agree that the mixed respiratory metabolic acidosis due to labour is a physiological aspect of birthing and is usually alleviated within 24 hours post natum (p.n.) (Comline \& Silver, 1972; Walser \& Maurer-Schweizer, 1978; Bostedt \& Bellinghausen, 1985; Busse et al., 1986; Szenci et al., 1988; Herpin et al., 1996; Varga et al., 2001; Gorlt, 2004; Richter, 2005; Bleul \& Götz, 2013).

During birth when the blood supply through the foetal-placental unit is intermittent the neonate is not only deprived of oxygen, but also of glucose and other nutrients (Mota-Rojas et al., 2011). The foetus and then the neonate maintains intra partum normoglycaemia via anaerobic glycolysis owing to its hypoxic state, causing an accumulation of lactic acid (Szenci, 2012; Bleul \& Götz, 2013). Lactic acid is the major metabolite responsible for decreased $\mathrm{pH}$ resulting in metabolic acidosis. The $\mathrm{BE}$, a calculated value, allows determining whether an acidosis is metabolic (Busse et al., 1986; Bleul \& Götz, 2013). Busse et al. (1986) demonstrated that thrifty lambs had a moderate negative BE which normalised within four hours p.n., most thrifty lambs even showed a positive BE 24 hours p.n.. Bostedt \& Bellinghausen (1985) also showed that the $\mathrm{BE}$, which had the highest individual variability, steadily rose far above zero until the fourth day of life. Glucose levels in all foals were at the lower limit of the reference range increasing continuously with the commencement of suck- 
ling. The drop in glucose in the first half hour of life is noteworthy, showing how quickly glucose reserves are exhausted and the dangers of inadequate suckling in the adaptation phase (Bostedt \& Bellinghausen, 1985). Comline \& Silver (1972) showed in their study with lambs that lactic acid began rising significantly one hour before parturition, reaching its maximum values 5-10 minutes p.n. The observations of Comline \& Silver (1972) showed a close relationship between the peri-natal $\mathrm{pH}$ fall and lactic acid rise. They also showed that the glucose levels behaved similarly to the lactic acid levels with a peak immediately $p . n$. In their model with calves, Walser \& Maurer-Schweizer (1978) demonstrated that the acidosis worsened in the first 10-15 minutes of life although thrifty neonates began breathing immediately after birth. They attributed this to the abolition of the oxygen-saving circulation, funneling oxygenated blood to the CNS, heart, and adrenal gland and the subsequently increased circulating lactic acid. Bleul \& Götz (2013) also observed increased L-lactate and $\mathrm{pCO}_{2}$ concentrations in thrifty calves, but a constant $\mathrm{pH}$, disagreeing with Comline \& Silver (1972). These values normalised within 48 and 4 hours, respectively.

\section{Dystocia}

A delayed or difficult parturition, dystocia, leads to a protracted expulsion and invariable hypoxia (Lombard et al., 2007; Taverne, 2008). If hypoxia persists due to dystocia it could have serious negative long-term effects on the survival of the neonate or be immediately fatal (Adams et al., 1991; Lopez \& Bildfell, 1992; Lombard et al., 2007; Bleul et al., 2010; Blomhoff Holm, 2012; Barrier et al., 2013). The cumulative effects of uterine contractions by pathologically prolonged labour, will lead to cord damage or rupture as well as premature detachment of the placenta (Herpin et al., 1996; Vaala, 1999; Taverne, 2008). In the late 70's Walser \& Maurer-Schweizer (1978) discussed the dangers of neonatal hypoxia, resulting in acidosis, which ultimately leads to death of individual cells. Szenci et al. (1988) and Walser \& MaurerSchweizer (1978) pointed out that a $\mathrm{pH}$ of 6.7 wass incompatible with life. Acidosis which is the most severe in disorders such as meconium aspiration syndrome, hypoxic-ischaemic encephalopathy or enterocolitis and potentially death, is often a consequence of dystocia (Vaala, 1999; Ikeda et al., 2000; Martinez-Burnes et al., 2002; Castro-Najera et al., 2006; Katz, 2006; Vidyasagar \& Zagariya, 2008; Kumar \& Paterson-Brown, 2010; Jacobson Misbe et al., 2011; Mokra \& Mokry, 2011; Armstrong et al., 2012). MotaRojas et al. (2005) showed in a study with 120 farrowing sows, through the administration of oxytocin, that enhanced myometrium contractions caused severe foetal distress with decreased foetal heart rates and increased meconium staining, leading to higher intra-partum mortality. Cord rupture facilitated placental detachment by causing a decrease in blood pressure and a collapse of the chorionic villi (Alonso-Spilsbury et al., 2005). Failure to establish breathing immediately after birth sustains the hypoxia-induced perinatum vasoconstriction of the lungs, intestines, kidneys, muscles and skin while keeping the blood flow to the CNS, heart and adrenal glands steady (oxygen-saving circulation) (Walser \& Maurer-Schweizer, 1978; Rurak et al., 1990; Weinberger et al., 2001; Martinez-Burnes et al., 2002; Alonso-Spilsbury et al., 2005; Szenci, 2012; Bleul \& Götz, 2013). This redistribution ensures the function of vital organs 
of the hypoxic foetus. Any form of dystocia can be the cause of extended labour, facilitating prolonged hypoxia, hypercapnia and acidosis (Adams et al., 1991; Lombard et al., 2007; Schulz, 2009; Bleul et al., 2010; Dutra \& Banchero, 2011; Barrier et al., 2013).

Events causing pathological hypoxia are:

- premature ablation of the placenta (Vaala, 1999; Alonso-Spilsbury et al., 2005);

- inadequate placenta perfusion, e.g. uterine torsion, maternal hypotension (Alonso-Spilsbury et al., 2005; CastroNajera et al., 2006);

- prolonged umbilical occlusion, e.g. sternal presentation (Alonso-Spilsbury et al., 2005; Schulz, 2009);

- foetal-maternal disproportion, e.g. heifer, male calf (Berglund et al., 2003; Mee et al., 2008);

- mal-presentation, -position, -posture (Schulz, 2009).

\section{Acid-base status in dystocia}

Busse et al. (1986) showed that unthrifty lambs exhibited only slight variations in the acid/base and blood gas homeostasis, the steep and severe drop in $\mathrm{pH}$ in the first 15 minutes of life was due to the insufficient respiratory response of the lambs. Unthrifty lambs showed $\mathrm{pH}$ levels of 7.08 on the average and a much longer period of convalescence than thrifty lambs. Unthrifty lambs that died within 24 hours of parturition showed diverging severity of acidosis, but all had in common a drastic drop in $\mathrm{pH}$ minutes after birth, with venous blood $\mathrm{pH}$ remaining extremely low until the fatal outcome. Highly significant differences in venous $\mathrm{pH}$ levels between the thrifty and unthrifty lambs could be shown up until 4 hours $p . n$.
Gorlt (2004), Richter (2005), Herfen (1999) and Varga et al. (2001) showed that neonates experiencing prolonged birth due to dystocia were distinctly less thrifty then eutotic young. They displayed noticeably low blood $\mathrm{pH}$ ranging from 7.03 to 7.26 . These animals had reduced respiratory activity, it took much longer to regulate their breathing rate and depth.

In contrast to other studies, in a study on 117 newborn piglets Herpin et al. (1996) reported that glucose levels were dramatically increased in neonates with prolonged parturition and showing unthriftiness. They surmised this to the increased secretion of stress hormones, such as catecholamines. The glucose utilisation due to reduced insulin secretion during hypoxia was still limited, available only to organs whose glucose uptake was insulin independent such as the CNS.

Walser \& Maurer-Schweizer (1978) and later Bleul \& Götz (2013) showed an increase in the $\mathrm{pCO}_{2}$ and the lactic acid directly p.n. due to reduced respiratory activity and the reperfusion of peripheral organs, having a deleterious effect on depressed neonates.

Busse et al. (1986) reported similar findings where the $\mathrm{BE}$ declined sharply $(-12 \mathrm{mmol} / \mathrm{l})$ and the $\mathrm{pCO}_{2}$ rose drastically $(84 \mathrm{mmHg})$ within 15 minutes p.n., owing to the inadequate respiratory response of the unthrifty lambs. The BE was normalised within 12 hours after birth and then reached positive values within 24 hours. Herfen (1999) confirmed a continuous drop in the BE within 10 minutes p.n. by up to 1.7 units establishing a direct correlation to the blood $\mathrm{pH}$ dynamics. Table 2 shows an overview of the results from previous studies.

When an organism falls in a hypoxic state, lactic acid is accumulated causing metabolic acidosis (Poulsen \& McGuirk, 
Table 2. Overview of $\mathrm{pH}, \mathrm{pCO}_{2}$ and base excess (BE), in unthrifty neonates ( $\mathrm{v}=$ venous blood, $\mathrm{a}=$ arterial blood, $n . \mathrm{a} .=$ not available)

\begin{tabular}{lllll}
\hline Reference & $\begin{array}{c}\text { Animal } \\
\text { species }\end{array}$ & $\begin{array}{c}\text { Mean } \\
\text { blood } \mathrm{pH}\end{array}$ & $\begin{array}{c}\mathrm{pCO}_{2} \\
(\mathrm{mmHg})\end{array}$ & $\begin{array}{c}\mathrm{BE} \\
(\mathrm{mmol} / \mathrm{L})\end{array}$ \\
\hline Walser \& Maurer-Schweizer (1978) & bovine & ca. $7.09(\mathrm{v})$ & $\mathrm{ca} .74$ & $\mathrm{ca}-10$ \\
Szenci et al. $(1988)$ & bovine & $7.14(\mathrm{v})$ & $66.76^{*}$ & -6.0 \\
Herfen (1999) & bovine & $7.11(\mathrm{v})$ & 81.14 & -6.9 \\
& & & & \\
Varga et al. $(2001)$ & bovine & $7.10(\mathrm{a})$ & 64.5 & -10.9 \\
Gorlt (2004) & equine & $7.26(\mathrm{v})$ & 72.76 & 2.5 \\
Richter (2005) & bovine & $7.14(\mathrm{a})$ & $65.56^{*}$ & -7.6 \\
Bleul \& Götz (2013) & bovine & $7.03(\mathrm{v})$ & 72.1 & n.a. \\
& & 10 min p.p. & & \\
\hline
\end{tabular}

*converted from kilopascals into millimeters mercury (Szenci et al., 1988: $8.9 \mathrm{kPa}$; Richter, 2005: $8.74 \mathrm{kPa})$.

2009; Bleul \& Götz, 2013). Reduced myocardial contractility, hypotension and eventual coagulopathies are the sequelae of the inevitable systemic metabolic acidosis (Seri \& Evans, 2001). The decline in $\mathrm{pH}$ will cause cell injury in multiple organs and the oxygen insufficiency will force a shift to an anaerobic metabolism (Alonso-Spilsbury et al., 2005; Bleul \& Götz, 2013). Meconium staining of the neonate or the amniotic fluids is a sign of peripartal distress.

\section{EFFECTS OF PATHOLOGICAL HYPOXIA ON THE ORGANS}

Oxygen deprivation (hypoxia) triggers a cascade of cellular biochemical events bringing about an alteration in cell function, as far as cell death (Galvin \& Collins, 2004; Alonso-Spilsbury et al., 2005; Alonso-Alconada et al., 2012). The cell loses its ability of efficient oxidative phosphorylation. The adenosine triphosphate (ATP) dependent sodium pump fails, exchange of ions across the cell membrane is disrupted and metabolites accumulate causing damage to the struc- tural and enzymatic integrity of the cell (Blomhoff Holm, 2012). A similar devastating effect has the overproduction of free radicals followed by oxidative stress and increased stimulation of pro-inflammatory cytokines (Alonso-Alconada et al., 2012). This multi-factorial process acts synergistically leading eventually to cellular necrosis (Alonso-Spilsbury et al. 2005).

Peri-partal hypoxia has various degrees of multisystemic effects (Vaala, 1999). Meconium staining of amniotic fluid is a macroscopic clinical sign for intrauterine hypoxia, foetal stress in animals as well as humans. Hypoxia experienced in utero causes an increased peristalsis of the intestines and a relaxation of the anal sphincter as well as increased respiratory movements resulting in the passage of meconium into the amniotic fluid causing a staining of the neonate and potential aspiration (Vaala, 1999; Martinez-Burnes et al., 2002; Castro-Najera et al., 2006; Mota-Rojas et al., 2012; Swarnam et al., 2012).

\section{Lungs}

The lungs develop in six stages, beginning as a ventral diverticulum in the foregut 
endoderm and completing their development after birth (Pringle, 1986; Caswell \& Williams, 2007). The lung progresses through phases of development, going through a series of epithelial-mesenchymal changes. The airway basement membrane region consists of three layers - the lamina lucida, lamina densa, lamina reticularis, and can be stained using the digested Periodic Acid-Schiff (PAS) reaction. Interstitial widening and increased cellularity are normal histological findings in children. Therefore it can be assumed that this would also pertain to neonatal animals (Colby et al., 2007). The bronchus-associated lymphoid tissue (BALT) is not present at birth, becoming established with increasing age. Lymphocytes are generally only present and grouped together in a pathological state in neonatal lungs (Colby et al., 2007). The mucosal epithelium of the conducting airways shows great cell diversity, depending upon the species and section of airways under consideration.

The lungs of most neonates continue to mature after partus, not being fully developed at birth (Pringle, 1986; Haworth $\&$ Hislop, 2003). The stage of microvascular maturation of the lung is a period of maturation of the air-blood interface, with a single capillary layer, which occurs after birth in nidicolous animals and peripartum in nidifugous animals (Roth-Kleiner \& Post, 2003; Caswell \& Williams, 2007).

Normal term foetuses may exhibit a minor sloughing of epithelial cells, but large amounts, especially if meconium is also present, indicate aspiration of amniotic fluid. This is a sign for increased intrauterine respiratory movement due to in utero hypoxia. Hypoxia can also be responsible for weak respiratory movement p.n. causing patchy congenital atelectasis due to incomplete expansion of the lung.
Acute hypoxia due to prolonged parturition may be the cause of MAS. Histological sections of affected lungs show amorphous yellow-orange meconium, keratin, and/or squamous epithelial cells. This is associated with atelectasis, haemorrhage, and a mild but diffuse alveolar infiltration of neutrophils, macrophages, and occasionally multinucleate cells (MartinezBurnes et al., 2002; Satas et al., 2003; Caswell \& Williams, 2007; Poulsen \& McGuirk, 2009; Mokra \& Calkovska, 2013). Satas et al. (2003) showed that global hypoxia ischaemia produced multiple small haemorrhages as well as deposition of fibrin debris in the alveoli.

Lungs are affected by prolonged uterine hypoxia, first mechanically through the aspiration of meconium contaminated amniotic fluid and second, on a cellular level due to the anaerobic metabolism (Alonso-Spilsbury et al., 2005; Bleul \& Götz, 2013).

Lung macrophages are activated by prolonged hypoxia episodes increasing the production and release of inflammatory mediators. This initiates the inflammatory cascades ending in the release of reactive oxygen and nitrogen species that can damage pulmonary cells (Weinberger et al., 2001; Mokra \& Calkovska, 2013).

With the onset of breathing p.n., the neonatal lungs experience increased alveolar oxygen tension and ensuing oxidative stress. The response of the organism is increased antioxidant defense, which is negatively influenced by pre-/perinatal hypoxic stress (Giles et al., 2002).

Neonates born with MAS experience respiratory distress, the clinical signs are caused by airway obstruction, impaired gas exchange, atelectasis or dystelectasis, pneumonia and/or surfactant dysfunction (Vaala, 1999; Zagariya et al., 2000). These structural and functional alterations 
have in turn major effect on the acid-base regulation resulting in acidosis (Lopez \& Bildfell, 1992). Clinical effects are not limited to the respiratory tract, since the acidosis and hypoxia affect all tissues in the body. Histological examinations of lungs from neonates that experienced respiratory distress from prolonged labour demonstrated squamous epithelial cells, meconium and inflammation after haematoxylin and eosin staining (Lopez \& Bildfell, 1992). Zagariya et al. (2000) showed in a rabbit pups model that meconium triggers an increased polymorphonuclear leukocytes response of the lung tissue.

Intrapulmonary neutrophil accumulation greatly increased the expression of pro-inflammatory chemotactic cytokines, phospholipase $\mathrm{A}_{2}$ and levels of $\mathrm{PGE}_{2}$, exacerbating inflammatory reactions of lung tissue and exerting a deleterious effect on alveolar cells (Zagariya et al., 2000; Vidyasagar \& Zagariya, 2008; Mokra \& Mokry, 2011). These inflammatory reactions caused increased vascular permeability leading to pulmonary oedema, proteinaceous exudate accumulation in the alveoli and an increased release of oxidative species potentially initiating increased apoptosis (Kirimi et al., 2003; Vidyasagar \& Zagariya, 2008).

\section{CLINICAL CONSEQUENCES OF PATHOLOGICAL HYPOXIA}

Prolonged intra-partum hypoxia causes unthriftiness, delayed first contact with the udder and weak suckling. This has negative effects on colostrum intake and causes a failure of passive transfer leading to hypogammaglobulinaemia and increased risk of infection, hypoglycaemia as well as a reduced absorption of other vital nutrients and minerals (Grongnet, 1984; Lopez \& Bildfell, 1992; Alonso-
Spilsbury et al., 2005; Lombard et al., 2007; Barrier et al., 2013). Low glucose and high lactate levels due to anaerobic metabolism and depleted hepatic glycogen can often be associated with depression of the neonates (Walser, 2009; Mota-Rojas et al., 2011). In his work with bovine neonates Linke (2013) showed that at the end of the first hour p.n. the lungs of thrifty born calves are still not fully ventilated, up to $80 \%$ cranially and $55 \%$ ventrally. It can be expected that the lungs of depressed neonates, which show lower respiratory activity, prolonged laying periods and incomplete left-right shunting of the cardio-vascular system, are even more poorly ventilated (Linke, 2013). Further diagnostic examinations with ultrasound, as established by Jung (2002), clearly showed increased atelectasis of the lungs by neonates that are unthrifty and showed clinical signs of amniotic fluids aspiration at birth. Some pathologies as pneumonia, hypoxic ischaemic encephalopathy, neonatal respiratory distress syndrome (nRDS), MAS, heart disease and necrotising enterocolitis are also commonly seen in neonates that experienced prolonged hypoxic episodes during birth (Touloukian et al., 1972; Donnelly et al., 1980; Clark et al., 1988; Lopez \& Bildfell, 1992; Vaala, 1999; Ikeda et al., 2000; Zagariya et al., 2000; Satas et al., 2003; Canpolat et al., 2006; Taylor \& Colgan, 2007; Faa et al., 2012; Lu et al., 2012).

\section{CONCLUSION}

Dystocia will always be a major risk during birth, it is therefore essential to minimise these hazards to reduce neonatal losses. To this end, it is indispensable to detect, identify and alleviate pathologies during birth in a timely manner. A good pregnancy monitoring should be ensured, 
combined with, when necessary, competent and professional assistance to increase survival chances and prevent disorders such as nRDS. This includes a targeted treatment with buffering substances and non-steroidal anti-inflammatory drugs, as well as oxygen supplementation and other reanimation measures.

\section{REFERENCES}

Adams, R., M. D. Holland, B. Aldridge, F. B. Garry \& K. G. Odde, 1991. Arterial blood sample collection from the newborn calf. Veterinary Research Communications, 15 , 387-394.

Alonso-Alconada, D., E. Hilario, F. J. Alvarez, J. Francisco \& A. Alvarez, 2012. Apoptotic cell death correlates with ROS overproduction and early cytokine expression after hypoxia-ischemia in fetal lambs. Reproductive Sciences, 19, 754-763.

Alonso-Spilsbury, M., D. Mota-Rojas, D. Villanueva-Garcia, J. Martinez-Burnes, $\mathrm{H}$. Orozco, R. Ramirez-Necoechea, A. L. Mayagoitia \& M. E Trujillo, 2005. Perinatal asphyxia pathophysiology in pig and human: A review. Animal Reproduction Science, 90, 1-30.

Armstrong, K., O. Franklin, D. Sweetman \& E. J. Molloy, 2012. Cardiovascular dysfunction in infants with neonatal encephalopathy. Archives of Disease in Children, 97, 372-375.

Barrier, A. C., M. J. Haskell, S. Birch, A. Bagnall, D. J. Bell, J. Dickinson, A. I. Macrae \& C. M. Dwyer, 2013. The impact of dystocia on dairy calf health, welfare, performance and survival. The Veterinary Journal, 195, 86-90.

Berglund, B., L. Steinbock, \& M. Elvander, 2003. Causes of stillbirth and time of death in Swedish Holstein calves examined post mortem. Acta Veterinaria Scandinavica, 44, 111-120.

Bleul, U. \& E. Götz, 2013. The effect of lactic acidosis on the generation and compen- sation of mixed respiratory-metabolic acidosis in neonatal calves. The Veterinary Record, 172, 528.

Bleul, U., B. Bircher, R. S. Jud \& A. P. N. Kutter, 2010. Respiratory and cardiovascular effects of doxapram and theophylline for the treatment of asphyxia in neonatal calves. Theriogenology, 73, 612-619.

Blomhoff Holm, M., 2012. The foetal response to acute perinatal hypoxia and the pathophysiological mechanisms behind hypoxic - ischemic encephalopathy. Dissertation, Faculty of Medicine, Oslo University.

Bostedt, H., \& W. Bellinghausen, 1985. Blutgasanalysen und Substratbestimmungen bei neugeborenen Fohlen. Tierärztliche Umschau, 40, 454-458.

Busse, G., H. Bostedt \& A. Sobiraj, 1986. Ergebnisse der Blutgasanalytik bei neugeborenen Lämmern unter besonderer Berücksichtigung der neonatalen Atemdepression. Deutsche Tierärztliche Wochenschrift, 93, 281-344.

Canpolat, F. E., M. Yurdakök, S. Özsoy, R. Hazıroğlu \& A. Korkmaz, 2006. Protective effects of recombinant human granulocyte colony stimulating factor in a rat model of necrotizing enterocolitis. Pediatric Surgery International, 22, 719-723.

Castro-Najera, J. A., J. Martinez-Burnes, D. Mota-Rojas, H. Cuevas-Reyes, A. Lopez, R. Ramirez-Necoechea, R. Gallegos-Sagredo \& M. Alonso-Spilsbury, 2006. Morphological changes in the lungs of meconium-stained piglets. Journal of Veterinary Diagnostic Investigation, 18, 622-627.

Caswell, J. L. \& K. J. Williams, 2007. Respiratory system. In: Jubb, Kennedy \& Palmer's Pathology of Domestic Animals, vol. $2,5^{\text {th }}$ edn, ed M. G. Maxie, Elsevier Saunders, Edinburgh, pp. 524-650.

Clark, D. A., D. M. Fornabaio, H. McNeill, K. M. Mullane, S. J. Caravella \& M. J. Miller, 1988. Contribution of oxygenderived free radicals to experimental necrotizing enterocolitis. American Journal of Pathology, 130, 537-542. 
Colby, T. V., K. O. Leslie \& S. A. Yousem, 2007. Lungs. In: Histology for Pathologists, $3^{\text {rd }}$ edn, ed S. E. Mills, Lippincott Williams \& Wilkins, Philadelphia, pp. 437-504.

Comline R. S. \& M. Silver, 1972. The composition of foetal and maternal blood during parturition in the ewe. Journal of Physiology, 222, 233-256.

Donnelly, W. H., R. L. Bucciarelli \& R. M. Nelson, 1980. Ischemic papillary muscle necrosis in stressed newborn infants. The Journal of Pediatrics, 96, 295-300.

Dutra, F. \& G. Banchero, 2011. Polwarth and Texel ewe parturition duration and its association with lamb birth asphyxia. Journal of Animal Science, 89, 3069-3078.

Faa, A., N. Iacovidou, T. Xanthos, A. Locci, P. Pampaloni, F. Aroni, A. Papalois, G. Faa \& V. Fanos, 2012. Hypoxia/reoxygenation-induced myocardial lesions in newborn piglets are related to interindividual variability and not to oxygen concentration. Clinics, 6, 503-508.

Galvin, N. \& D. Collins, 2004. Perinatal asphyxia syndrome in the foal: Review and a case report. Irish Veterinary Journal, 57, 707-714.

Giles, B. L., H. Suliman, L. B. Mamo, C. A. Piantadosi, T. D. Oury \& E. NozikGrayck, 2002. Prenatal hypoxia decreases lung extracellular superoxide dismuates expression and activity. American Journal of Physiology - Lung Cellular and Molecular Physiology, 283, 549-554.

Gorlt, R., 2004. Untersuchung zum Blutgasund Säure-Basen-Status beim neugeborenen Fohlen mittels netzunabhängiger Messmethode unter Berücksichtigung des Giessener Vorsorgeprogramms. Doctoral thesis, Justus-Liebig University, Giessen.

Grongnet, J. F., 1984. Metabolic consequences of induced hypoxia in newborn lambs. $A n$ nales de Recherches Vétérinaires, 15, 1728.

Haworth, S. G. \& A. A. Hislop, 2003. Lung development - the effects of chronic hypoxia. Seminars in Neonatology, 8, 1-8.
Herfen, K., 1999. Zur Säure-Basen-Statuts bei neugeborenen Kälbern in den ersten Lebenstagen unter besonderer Berücksichtigung differenter Vitalitätsstituationen. Berliner und Münchener Tierärztliche Wochenschrift, 112, 166-171.

Herpin P., J. Le Dividich, J.C. Hulin, M. Fillaut, F. De Marco \& R. Bertin, 1996. Effects of the level of asphyxia during delivery on viability at birth and early postnatal vitality of newborn pigs. Journal of Animal Science, 74, 2067-2075

Ikeda, T., Y. Murata, E. J. Quilligan, J. T. Parer, T. Murayama \& M. Koono, 2000. Histologic and biochemical study of the brain, heart, kidney, and liver in asphyxia caused by occlusion of the umbilical cord in near-term fetal lambs. American Journal of Obstetrics and Gynecology, 182, 449-457.

Jacobson Misbe, E. N., T. L. Richards, R. J. McPherson, R. M. Burbacher \& S. E. Juul, 2011. Perinatal asphyxia in a nonhuman primate model. Developmental Neuroscience, 33, 210-221.

Jung, C., 2002. Sonographie der Lunge und des Abdomens beim bovine Neonaten unter besonderer Berücksichtigung pathologischer Veränderungen Doctoral thesis, Justus-Liebig University, Giessen.

Katz, L., 2006. Perinatal asphyxia syndrome in a quarter horse foal. Veterinary Clinics of North America: Equine Practice, 22, 193208.

Kirimi, E., O. Tuncer, M. Kosem, E. Ceylan, A. Tas, I. Tasal, R. Balahoroğlu \& H. Caksen, 2003. The effects of prednisolone and serum malondialdehyde levels in puppies with experimentally induced meconium aspiration syndrome. Journal of International Medical Research, 31, 113-122.

Kumar, S. \& S. Paterson-Brown, 2010. Obstetric aspects of hypoxic ischemic encephalopathy. Early Human Development, 86, 339-344.

Linke, B., 2013. Computer tomographic illustration of the development of the pulmonary function in bovine neonates until the twenty-first day postnatum. Veterinary 
Medicine International, http://dx.doi.org/ 10.1155/2013/157960.

Lombard, J. E., F. B. Garry, S. M. Tomlinson, \& L. P. Garber, 2007. Impacts of dystocia on health and survival of dairy calves. Journal of Dairy Science, 90, 1751-1760.

Lopez, A. \& R. Bildfell, 1992. Pulmonary inflammation associated with aspirated meconium and epithelial cells in calves. Veterinary Pathology, 29, 104-111.

Lu, Y. Z., C. C. Wu, Y. C. Huang, C. Y. Huang, C. Y. Yang, T. C. Lee, C. F. Chen \& L. C. H. Yu, 2012. Neutrophil priming by hypoxic preconditioning protects agains epithelial barrier damage and enteric bacteril translocation in intestinal ischemia/ reperfusion. Laboratory Investigation, 92, 783-796.

Martinez-Burnes, J., A. Lopez, G. M. Wright, W. P. Ireland, D. W. Wadowska \& G. V. Dobbin, 2002. Microscopic changes induced by the intra-tracheal inoculation of amniotic fluid and meconium in the lung of neonatal rats. Histology and Histopathology, 17, 1067-1076.

Mee, J. F., D. P. Berry \& A. R. Cromie, 2008. Prevalence of, and risk factors associated with, perinatal calf mortality in pasturebased Holstein-Friesian cows. Animal, 2, 613-620.

Mokra, D. \& A. Calkovska, 2013. How to overcome surfactant dysfunction in meconium aspiration syndrome? Respiratory Physiology \& Neurobiology, 187, 58-63.

Mokra, D. \& J. Mokry, 2011. Glucocorticoids in the treatment of neonatal meconium aspiration syndrome. European Journal of Pediatrics, 170, 1495-1505.

Mota-Rojas, D., H. Orozco-Gregorio, D. Villanueva-Garcia, H. Bonilla-Jaime, X. Suarez-Bonilla, R. Hernandez-Gonzalez, P. Roldan-Santiago \& M. E. Trujillo-Ortega, 2011. Foetal and neonatal energy metabolism in pigs and humans: A review. Veterinarni Medicina, 56, 215-225.

Mota-Rojas, D., J. Martinez-Burnes, D. Villanueva-Garcia, P. Roldan-Santiago, M. E. Trujillo-Ortega, H. Orozco-Gregorio, H.
Bonilla-Jaime \& A. Lopez-Mayagoitia, 2012. Animal welfare in the newborn piglet: A review. Veterinarni Medicina, 57, 338-349.

Mota-Rojas, D., J. Martínez-Burnes, M. E. Trujillo, A. López, A. M. Rosales, R. Ramírez, H. Orozco, A. Merino \& M. Alonso-Spilsbury, 2005. Uterine and fetal asphyxia monitoring in parturient sows treated with oxytocin. Animal Reproduction Science, 86, 131-141.

Patterson, D. J., R. A. Bellows, P. J. Burfening \& J. B. Carr, 1987. Occurrence of neonatal and postnatal mortality in range beef cattle. I. Calf loss incidence from birth to weaning, backward and breech presentations and effects of calf loss on subsequent pregnancy rate of dams. Theriogenology, 28, 557-571.

Poulsen, K. P. \& S. M. McGuirk, 2009. Respiratory disease of the bovine neonate. Veterinary Clinics of North America: Food Animal Practice, 25, 121-137.

Pringle, K., 1986. Human fetal lung development and related animal models. Clinical Obstetrics \& Gynecology, 29, 502-513.

Richter, B., 2005. Prognostische Aussagekraft arterieller gegenüber venöser Blutgasparameter im wiederholten Messrhythmus hinsichtlich des Schweregrades des neonatalen Atemnotsyndroms beim Kalb. Doctoral thesis, Justus-Liebig University, Giessen, 198 pages.

Roth-Kleiner, M. \& M. Post, 2003. Genetic control of lung development. Biology of the Neonate, 84, 83-88.

Rurak, D. W., B. S. Richardson, J. E. Patrick, L. Carmichael \& J. Homan, 1990. Blood flow and oxygen delivery to fetal organs and tissues during sustained hypoxemia. American Journal of Physiology, 258, R1116-R1122.

Satas, S., E. M. Loberg, H. Porter, A. Whitelaw, P. A. Steen \& M. Thoreson, 2003. Effect of global hypoxia-ischaemia followed by $24 \mathrm{~h}$ of mild hypothermia on organ pathology and biochemistry in a newborn pig 
survival model. Biology of the Neonate, 83, 146-156.

Schultz, J., 2009. Prinzipien der Neonatologie. In Geburtshilfe bei Haustiere, $1^{\text {st }}$ edn, eds W. Busch \& J. Schulz, Enke, Stuttgart, pp. $159-175$.

Schulz, J., 2009. Prinzipien der Neonatologie. In: Geburtshilfe bei Haustiere, $1^{\text {st }}$ edn, eds W. Busch \& J. Schulz, Enke, Stuttgart, pp. $159-175$.

Seri, I. \& J. Evans, 2001. Controversies in the diagnosis and management of hypotension in the newborn infant. Current Opinion in Pediatrics, 13, 116-123.

Swarnam, K., A. S. Soraisham \& S. Sivanandan, 2012. Advances in the management of meconium aspiration syndrome. International Journal of Pediatrics, http://dx.doi. org/10.1155/2012/359571.

Szenci, O., 2012. Diagnosis of perinatal wellbeing of dairy calves. Lucrări Ştiinţifice Seria Zootehnie, 57, 3-11.

Szenci, O., M. A. Taverne, S. Bakonyi \& A. Erdödi, 1988. Comparison between preand postnatal acid-base status of calves and their perinatal mortality. The Veterinary Quarterly, 10, 140-144.

Taverne, M. A., 2008. The relation between the birth process and the condition of the newborn piglet and calf. Veterinary Research Communications, 32, Suppl 1, 93 98.

Taverne, M. \& D. E. Noakes, 2009. Parturition and the care of parturient animals, including the newborn. In: Veterinary Reproduction and Obstetrics, eds. D. E. Noakes, T. J. Parkinson \& G. C. W. England, $9^{\text {th }}$ edn, Saunders/Elsevier, London, pp. 76-205.

Taylor, C. T. \& S. P. Colgan, 2007. Hypoxia and gastrointestinal disease. Journal of Molecular Medicine, 85, 1295-1300.

Touloukian, R. J., J. N. Posch \& R. Spencer, 1972. The pathogenesis of ischemic gastroenterocolitis of the neonate: selective gut mucusal ischemia in asphyxiated neonatal piglets. Journal of Pediatric Surgery, 7, 194-205.
Tucker, J. M. \& J. C. Hauth, 1990. Intrapartum assessment of fetal wel-being. Clinical Obstetrics and Gynecology, 33, 515-525.

Vaala, W. E., 1999. Peripartum asphyxia syndrome in foals. In: Proceedings of the Annual Convention of the AAEP, 45, 247-253.

Varga, J., L. Mester, L. Börzsönyi, P. Lekeux \& O. Szenci, 2001. Improved pulmonary adaptation in newborn calves with postnatal acidosis. The Veterinary Journal, 162, 226-232.

Vidyasagar, D. \& A. Zagariya, 2008. Studies of meconium-induced lung injury: Inflammatory cytokine expression and apoptosis. Journal of Perinatology, 28, 102-107.

Walser, K. \& H. Maurer-Schweizer, 1978. Die Asphyxie der Neugeborenen. Tierarztliche Praxis, 6, 451-459.

Walser, K., 2009. Chapter 1.4 Atmung. In: Neugeborenen- und Säuglingskunde der Tiere, $1^{\text {st }}$ edn, eds K. Walser \& H. Bostedt, Enke Verlag, Stuttgart, pp. 14-18.

Weinberger, B., T. Carbone, S. England, A. M. Kleinfed, M. Hiatt \& T. Hegyi, 2001. Effects of perinatal hypoxia on serum unbound free fatty acids and lung inflammatory mediators. Biology of the Neonate, 79, 61-66.

Zagariya, A., R. Bhat, B. Uhal, S. Navale, M. Freidine \& D. Vidyasagar, 2000. Cell death and lung cell histology in meconium aspirated newborn rabbit lung. European Journal of Pediatrics, 159, 819-826.

Paper received 06.01.2017; accepted for publication 07.04.2017

\section{Correspondence:}

Plamen Georgiev

Department of Obstetrics, Reproduction and Reproductive Disorders, Faculty of Veterinary Medicine, 6000 Stara Zagora, Bulgaria, e-mail: plana@abv.bg 